\title{
Pengembangan media berbasis audio melalui podcast sporify untuk menunjang pembelajaran jarak jauh pada mata pelajaran pengelolaan bisnis ritel
}

\author{
Nihayatul Umniyyah, Rachmad Hidayat* \\ Universitas Negeri Malang, Jl. Semarang No. 5 Malang, Jawa Timur, Indonesia \\ *Penulis korespondensi, Surel: rachmad.hidayat.fe@um.ac.id
}

Paper received: 2-1-2021; revised: 23-1-2021; accepted: 30-1-2021

\begin{abstract}
Abstrak
Penelitian dilaksanakan karena adanya potensi dan masalah yang terjadi di lapangan. Tujuan dari penelitian ini meliputi (1) menghasilkan media pembelajaran berbasis audio menggunakan podcast di Spotify sebagai penunjang PJJ pada mata pelajaran Pengelolaan Bisnis Ritel; (2) mengetahui tingkat kelayakan media pembelajaran menggunakan podcast di Spotify; (3) mengetahui keefektifan media pembelajaran berbasis audio menggunakan podcast sebagai penunjang Pembelajaran Jarak Jauh (PJJ). Model penelitian pengembangan ini didasarkan pada prosedur penelitian yang diungkapkan oleh Sugiyono dan telah dimodifikasi sesuai dengan kebutuhan peneliti dengan tahapan berikut, (1) potensi dan masalah, (2) pengumpulan data, (3) desain produk, (4) validasi I oleh ahli, (5) revisi berdasarkan validasi ahli, (6) validasi II oleh ahli, (7) uji coba lapangan, (8) revisi produk dari uji coba lapangan, dan (9) produksi massal. Pengembangan media pembelajaran ini divalidasi oleh ahli materi, ahli media, dan ahli bahasa. Hasil yang diperoleh dari validasi ahli materi sebesar $85,45 \%$ dengan kategori sangat layak, validasi ahli media sebesar $98,46 \%$ dengan kategori sangat layak, validasi ahli bahasa sebesar $94,00 \%$ dengan kategori sangat layak, dan hasil uji coba lapangan memperoleh skor $93,04 \%$ dengan kategori sangat layak. Penelitian dan pengembangan ini diterapkan pada peserta didik kelas XI Bisnis Daring dan Pemasaran di SMK Negeri 1 Malang. Efektivitas media pembelajaran berbasis audio menggunakan podcast di Spotify diukur dengan membandingkan hasil posttest antara kelas eksperimen dan kelas kontrol. Hasil yang diperoleh adalah $\mathrm{t}$ hitung $=4,965>\mathrm{t}$ tabel $=1,671$, yaitu terdapat perbedaan yang signifikan hasil rata-rata posttest antara kelas eksperimen dan kelas kontrol. Sehingga, dapat disimpulkan bahwa pada penelitian pengembangan ini media layak dan efektif dalam menunjang pembelajaran jarak jauh
\end{abstract}

Kata kunci: media pembelajaran, podcast, spotify, PJJ, pengelolaan bisnis ritel

\section{Pendahuluan}

Pendidikan merupakan salah satu pilar utama bagi perkembangan peradaban suatu bangsa. Dalam proses perkembangan pendidikan memerlukan andil dari perkembangan teknologi sehingga akan menjembatani pencapaian perkembangan pendidikan. Saat ini, peserta didik yang duduk di sekolah menengah atas merupakan generasi Z. generasi Z merupakan kelompok individu kelahiran tahun 1995-2010 yang mempunyai karakteristik sangat familiar dengan perkembangan teknologi, bersahabat dalam menggunakan beberapa aplikasi, intens menggunakan media sosial dan mempunyai pemikiran yang cepat untuk berpindah-pindah (Wibawanto: 2016).

Sejak Maret 2020 Indonesia terdampak wabah Coronavirus Disease (Covid-19) yang mengakibatkan proses pembelajaran harus dilaksanakan jarak jauh. Hal itu sesuai dengan Surat Edaran nomor 4 tahun 2020, bahwa Menteri Pendidikan dan Kebudayaan Republik Indonesia memutuskan untuk penerapan proses belajar dari rumah melalui pembelajaran jarak jauh yang selanjutnya disebut PJJ. Menurut Smaldino, dkk (2014:168) menjelaskan mengenai distance learning atau pembelajaran jarak jauh adalah kegiatan belajar dengan 
memanfaatkan telekomunikasi yang meliputi teknologi dan media konfigurasi seperti audio, video dan website. Maka dari itu, guru harus memikirkan alternatif media pembelajaran yang sesuai dengan karakter peserta didik dan kondisi lapangan saat itu.

Dalam lingkup pembelajaran, media digunakan sebagai perantara yang memfasilitasi komunikasi dalam proses pembelajaran, sehingga pesan dan materi yang disampaikan oleh guru dapat diterima baik oleh peserta didik (Smaldino, dkk, 2014:14). Pemilihan media pembelajaran harus sesuai dengan karakteristik peserta didik sebagai pengguna utama dari media pembelajaran tersebut sehingga akan meningkatkan kualitas pengalaman belajar peserta didik (Donovan dan Bransford dalam Smaldino, dkk, 2014:31). Kriteria pemilihan media pembelajaran yang diungkapkan oleh Abidin (2016:12) meliputi: 1) capaian tujuan pembelajaran, 2) karakter peserta didik, 3) stimulus belajar yang digunakan, 4) keadaan lingkungan, 5) kondisi setempat, dan 6) luasnya jangkauan.

Berdasarkan hasil observasi yang dilaksanakan pada 10 Agustus 2020 sampai 18 September 2020, peneliti melihat permasalahan yang terjadi di SMK Negeri 1 Malang. Peserta didik kesulitan dalam mengakses materi pembelajaran karena minimnya kuota internet yang dimiliki. Ibu Sri Lestari selaku guru mata pelajaran Pengelolaan Bisnis Ritel di SMK N 1 memaparkan bahwa, pihak sekolah telah memberikan subsidi kuota internet, namun kuota internet yang diberikan tidak mencukupi kebutuhan pembelajaran tiap harinya. Hal tersebut berdampak pada terhambatnya proses pembelajaran yang ada di SMK Negeri 1 Malang khususnya untuk Kompetensi Keahlian Bisnis Daring dan Pemasaran.

Sehingga peneliti ingin memberikan alternatif media pembelajaran yang dapat menunjang proses pembelajaran jarak jauh dengan menggunakan podcast di Spotify. Dimana podcast merupakan media yang dapat diakses melalui perangkat apapun dan tidak banyak mengonsumsi kuota internet. Smaldino, dkk (2014:273) mengungkapkan bahwa secara bahasa podcast berasal dari kata ipod dan broadcasting yang mempunyai makna suatu berkas berupa rekaman audio dalam format MP3 yang disebarkan melalui internet. Berkas tersebut dapat diakses penggunanya baik dalam jangkauan aliran internet maupun didengarkan setelah diunduh terlebih dahulu. Sehingga dapat digunakan sebagai perantara penyampaian materi dalam proses pembelajaran jarak jauh.

Penelitian mengenai penggunaan podcast sebagai media pembelajaran jarak jauh sebelumnya telah dilakukan oleh Koppelman (2013) dengan hasil penelitian bahwa peserta didik menyukai media pembelajaran menggunakan podcast sehingga pembelajaran jarak jauh dapat berjalan secara efisien.

Abidin dan Widodo (2018) juga telah melakukan penelitian pengembangan media audio berbasis podcast materi story telling mata pelajaran Bahasa Inggris. Hasil yang didapatkan adalah media pembelajaran tersebut layak digunakan dan efektif dalam proses kegiatan pembelajaran.

Selain itu Susilowati, Sutama, dan Faiziyah (2020) telah melakukan penelitian penerapan podcast pada aplikasi Spotify sebagai media pembelajaran matematika di tengah pandemi Covid-19. Kesimpulan dari penelitian ini adalah podcast mampu menunjang pembelajaran peserta didik dalam memahami materi dan podcast dapat menjadi alternatif media pembelajaran jarak jauh (PJJ). 
Berdasarkan paparan di atas maka tujuan dari penelitian "Pengembangan Media Pembelajaran Berbasis Audio Menggunakan Podcast di Spotify sebagai Penunjang Pembelajaran Jarak Jauh (PJJ)" meliputi: 1) menghasilkan media pembelajaran berbasis audio menggunakan podcast di Spotify sebagai penunjang pembelajaran jarak jauh pada mata pelajaran pengelolaan bisnis ritel, 2) mengetahui tingkat kelayakan media pembelajaran menggunakan podcast di Spotify pada mata pelajaran Pengelolaan Bisnis Ritel, 3) mengetahui keefektifan media pembelajaran berbasis audio menggunakan podcast sebagai penunjang Pembelajaran Jarak Jauh (PJJ) pada mata pelajaran Pengelolaan Bisnis Ritel.

\section{Metode}

Metode yang digunakan dalam penelitian ini adalah metode penelitian dan pengembangan dengan nama lain Research and Development (R\&D) yaitu metode penelitian yang bertujuan untuk menghasilkan produk dan diuji efektivitasnya (Sugiyono, 2017:407). Dalam penelitian ini menggunakan penelitian dan pengembangan oleh Sugiyono (2017:409) yang terdiri dari 10 tahapan yang harus ditempuh.

Teknik pengambilan data menggunakan wawancara, observasi, angket, dan tes. Data yang diperoleh terdiri dari data kuantitatif yang diperoleh dari hasil angket validasi dan hasil tes dan data kualitatif diperoleh dari hasil observasi, wawancara, komentar, kritik dan saran yang ditulis pada angket. Subjek uji coba dalam penelitian dan pengembangan ini yaitu 1 ahli materi, 1 ahli media, 1 ahli bahasa, 29 peserta didik kelas eksperimen dan 30 peserta didik kelas kontrol.

\section{Hasil dan Pembahasan}

\subsection{Proses Pengembangan Media Pembelajaran}

Pengembangan media pembelajaran berbasis audio menggunakan podcast di Spotify pada Mata Pelajaran Pengelolaan Bisnis Ritel kompetensi dasar menganalisis dan menyusun laporan tentang lembaga waralaba dan perananannya menggunakan pengembangan yang diungkapkan oleh Sugiyono yang telah dimodifikasi oleh peneliti menyesuaikan dengan keadaan di lapangan tanpa mengurangi esensi dari penelitian ini. Hasil dari modifikasi tersebut prosedur penelitian terdiri dari 9 tahapan yang meliputi, (1) potensi dan masalah, (2) pengumpulan data, (3) desain produk, (4) validasi I oleh ahli, (5) revisi berdasarkan validasi ahli, (6) validasi II oleh ahli, (7) uji coba lapangan, (8) revisi produk dari uji coba lapangan, dan (9) produksi massal.

\subsection{Hasil Penyajian Data}

Validasi ahli materi pada pengembangan media yang berkaitan kesesuaian materi yang ada di dalam podcast yang dikembangkan oleh peneliti. Penilaian didasarkan pada pertanyaan pada lembar validasi, validator diperkenankan memberikan komentar, kritik, dan saran yang selanjutnya digunakan sebagai dasar revisi produk. Berdasarkan analisis penilaian validasi ahli materi yang pertama memperoleh nilai $80,00 \%$ dengan kategori layak dengan sedikit perbaikan (Akbar, 2017:82). Setelah dilakukan revisi produk, peneliti melakukan validasi tahap kedua oleh validator ahli materi untuk memastikan bahwa revisi yang telah dilakukan sesuai dengan komentar, kritik dan saran yang diberikan. Nilai yang diperoleh adalah $85,45 \%$ dengan kategori sangat layak tanpa perbaikan (Akbar, 2017:82). 
Validasi oleh ahli materi dalam penelitian pengembangan ini ditujukan untuk menilai kelayakan media yang dikembangkan. Selain pertanyaan yang diberikan, validator dapat memberikan komentar, kritik, dan saran yang digunakan sebagai dasar perbaikan produk. Hasil dari validator ahli media memperoleh nilai 98,46\% dengan kategori sangat layak tanpa perbaikan (Akbar, 2017:82) sehingga tidak diperlukan validasi kedua dari pihak validasi ahli media.

Validasi ahli bahasa diperlukan untuk menilai tata bahasa, artikulasi, dan intonasi pada podcast. Hasil validasi ahli bahasa tahap pertama memperoleh nilai 76,00\% dengan kategori layak dan dibutuhkan sedikit perbaikan. Setelah melakukan revisi produk berdasarkan komentar, kritik dan saran yang diberikan, dilakukan validasi ahli bahasa tahap kedua dan memperoleh nilai 94,00\% dengan kategori sangat layak tanpa perbaikan (Akbar, 2017:82).

\subsection{Hasil Analisis Data Tes}

Penggunaan analisis data tes adalah untuk mengetahui efektivitas media pembelajaran berbasis audio menggunakan podcast di Spotify sebagai penunjang pembelajaran jarak jauh (PJJ) dengan membandingkan hasil tes kelas eksperimen dan kelas kontrol. Hasil yang diperoleh adalah $t_{\text {hitung }}=4,956>t_{\text {tabel }}=1,671$, sehingga dapat ditarik kesimpulan bahwa hasil tes antara kelas eksperimen dan kelas kontrol terdapat perbedaan yang signifikan.

\subsection{Produk yang Dikembangkan}

Produk yang dikembangkan dalam penelitian ini berupa media pembelajaran berbasis audio menggunakan podcast pada mata pelajaran pengelolaan bisnis ritel kompetensi dasar menganalisis dan menyusun laporan tentang lembaga waralaba dan peranannya. Pada podcast ini materi disajikan dalam beberapa episode disesuaikan dengan pertemuan dalam pembelajaran.

Proses penelitian dan pengembangan menggunakan prosedur yang diungkapkan oleh Sugiyono yang telah dimodifikasi menyesuaikan dengan keadaan lapangan. Langkah pertama adalah menganalisis potensi dan masalah yang terjadi di lapangan melalui observasi dan wawancara kepada Guru Mata Pelajaran Pengelolaan Bisnis Ritel.

Berdasarkan observasi dan wawancara tersebut diketahui kendala yang dialami peserta didik dalam proses pembelajaran jarak jauh dikarenakan minimnya kuota internet yang dimiliki sehingga mereka terhambat dalam memahami materi yang disampaikan guru.

Setelah melakukan analisis masalah, peneliti mengembangkan produk awal yang selanjutnya divalidasi oleh ahli materi, ahli media, ahli bahasa, dan 29 peserta didik kelas XI BDP 1 Bisnis Daring dan Pemasaran SMK Negeri 1 Malang sebagai pengguna media pembelajaran podcast. Setelah melalui tahap revisi dan validasi tahap kedua maka produk media pembelajaran berbasis audio menggunakan podcast di Spotify siap digunakan untuk menunjang PJJ. 


\subsection{Hasil Analisis Data}

Penelitian ini adalah penelitian dan pengembangan yang menghasilkan media pembelajaran berbasis audio menggunakan podcast di Spotify sebagai penunjang pembelajaran jarak jauh.

Setelah peneliti melewati tahapan penelitian melalui validasi ahli materi, validasi ahli media, validasi ahli bahasa dan uji coba lapangan dapat disimpulkan bahwa media dikategorikan layak digunakan dalam proses pembelajaran dengan rincian $85,45 \%$ untuk penghitungan validasi ahli materi, 98,46\% untuk penghitungan validasi ahli media, 94\% untuk penghitungan validasi ahli bahasa, dan 93,04\% untuk penghitungan hasil uji coba lapangan.

Nilai hasil tes yang diperoleh dianalisis melalui uji t menggunakan taraf signifikansi 5\% dan nilai $\mathrm{df}=57$ menunjukkan tabel 1,671 dan $t_{\text {hitung }} 4,956$ dengan artian $t_{\text {hitung }}$ lebih besar daripada $t_{\text {tabel. }}$. Sehingga dapat disimpulkan bahwa media pembelajaran efektif digunakan sebagai penunjang pembelajaran jarak jauh.

Penelitian ini didukung dengan penelitian terdahulu oleh Asmi dkk (2019) yang mengembangkan media pembelajaran audio berbasis podcast pada materi sejarah lokal di Sumatera Selatan. Hasilnya menunjukkan bahwa media pembelajaran audio berbasis podcast dinilai valid dengan nilai 4,78 dari ahli materi, 4,38 dari ahli bahasa, dan 4 dari ahli media. Uji coba lapangan diterapkan pada 28 mahasiswa Universitas Sriwijaya Program Studi Pendidikan Sejarah memperoleh rata-rata pretest yaitu 36,42 dengan kategori sangat rendah dan kemudian rata-rata posttest yaitu 82.32 dengan kategori baik. Terjadi peningkatan sebesar $45,9 \%$ dan nilai $\mathrm{N}$-gain 0,72 jika $0,72 \geq 0,7$ maka termasuk dalam kategori tinggi. Hal ini menunjukan media Audio berbasis Podcast pada materi Sriwijaya telah berhasil diterapkan dan memiliki nilai kevalidan dan memiliki dampak efektifitas.

\section{Simpulan}

Berdasarkan hasil pengembangan ini menghasilkan media pembelajaran berbasis audio menggunakan podcast di Spotify sebagai penunjang pembelajaran jarak jauh (PJJ) pada mata pelajaran pengelolaan bisnis ritel kompetensi dasar menganalisis dan menyusun laporan tentang lembaga waralaba dan peranannya yang terdiri dari beberapa episode disesuaikan dengan materi pembelajaran yang akan disampaikan setiap pertemuannya. Media pembelajaran podcast divalidasi oleh satu orang validator ahli materi, satu orang validator ahli media, satu orang validator ahli bahasa, dan dua puluh sembilan peserta didik kelas XI Bisnis Daring dan Pemasaran SMK Negeri 1 Malang. Dalam penelitian ini media telah memenuhi kriteria kelayakan setelah diadakan uji coba pada ahli materi dengan tingkat kelayakan $85,45 \%$, ahli media dengan tingkat kelayakan $98,46 \%$, ahli bahasa dengan tingkat kelayakan $94,00 \%$, dan uji coba pengguna dengan tingkat kelayakan 93,04\%. Sedangkan untuk mengukur efektivitas media pembelajaran podcast sebagai penunjang pembelajaran jarak jauh dapat dilihat pada hasil tes antara kelas eksperimen dan kelas kontrol yang memperoleh hasil tabel 1,671 dan thitung 4,956. Sehingga dapat disimpulkan bahwa media pembelajaran efektif digunakan sebagai penunjang pembelajaran jarak jauh.

\section{Daftar Rujukan}

Abidin, J. D., \& Widodo, S. (2018). Pengembangan Media Audio Berbasis Podcast Materi Story Telling Mata Pelajaran Bahasa Inggris Kelas X Jurusan Rekayasa Perangkat Lunak Smk Krian 1 Sidoarjo. Jurnal Mahasiswa Teknologi Pendidikan, 9(2). 
Jurnal Ekonomi, Bisnis dan Pendidikan, 1(1), 2021, 34-39

Abidin, Z. (2017). Penerapan pemilihan media pembelajaran. Edcomtech Jurnal Kajian Teknologi Pendidikan, 1(1), 9-20.

Akbar, S. D. (2017). Instrumen Perangkat Pembelajaran cetakan kelima. Bandung: PT Remaja Rosdakarya.

Asmi, A. R. (2019). Pengembangan Media Pembelajaran Audio berbasis Podcast pada Materi Sejarah Lokal di Sumatera Selatan. Historia: Jurnal Pendidik dan Peneliti Sejarah, 3(1): 49-56. https://doi.org/10.17509/historia.v3i1.21017

Koppelman, H. (2013). Using podcasts in distance education. Proceedings of the International Conference ELearning 2013, 303-310.

Smaldino, S. E., Lowther, D. L., \& Russell, J. D. (2014). Instructional technology \& media for learning: Teknologi pembelajaran dan media untuk belajar. Prenada Media.

Sugiyono. (2008). Metode penelitian pendidikan:(pendekatan kuantitatif, kualitatif dan R \& D). Alfabeta.

Sukmadinata, N. S. (2012). Metode Penelitian Pendidikan, PT Remaja Rosdakarya.

Susilowati, R. D., Sutama, S., \& Faiziyah, N. (2020). Penerapan Podcast pada Aplikasi Spotify Sebagai Media Pembelajaran Matematika di Tengah Pandemi Covid-19. Jurnal Riset Pendidikan dan Inovasi Pembelajaran Matematika (JRPIPM), 4(1), 68-78.

Wibawanto, W., \& Ds, S. S. M. (2017). Desain dan pemrograman multimedia pembelajaran interaktif. Cerdas Ulet Kreatif Publisher. 